\title{
CHANCES OF AIRBORNE SAR IN THE INVESTIGATION OF BURIED ARCHAEOLOGICAL SITES IN MOIST SOIL IN BAVARIA
}

\author{
Roland Linck, Jens Fischer, Rebecca Casement
}

Presses universitaires de Rennes | «ArcheoSciences »

2021/1 n 45-1 | pages 175 à 178

ISSN 1960-1360

ISBN 9782753585874

Article disponible en ligne à l'adresse :

https://www.cairn.info/revue-archeosciences-2021-1-page-175.htm

Distribution électronique Cairn.info pour Presses universitaires de Rennes.

(C) Presses universitaires de Rennes. Tous droits réservés pour tous pays.

La reproduction ou représentation de cet article, notamment par photocopie, n'est autorisée que dans les limites des conditions générales d'utilisation du site ou, le cas échéant, des conditions générales de la licence souscrite par votre établissement. Toute autre reproduction ou représentation, en tout ou partie, sous quelque forme et de quelque manière que ce soit, est interdite sauf accord préalable et écrit de l'éditeur, en dehors des cas prévus par la législation en vigueur en France. Il est précisé que son stockage dans une base de données est également interdit. 


\section{ArcheoSciences}

Revue d'archéométrie

45-1| 2021

14th International Conference of Archaeological Prospection

\section{Chances of Airborne SAR in the Investigation of Buried Archaeological Sites in Moist Soil in Bavaria}

Roland Linck, Jens Fischer and Rebecca Casement

\section{(2) OpenEdition}

Journals

Electronic version

URL: https://journals.openedition.org/archeosciences/9413

DOI: 10.4000/archeosciences. 9413

ISSN: 2104-3728

\section{Publisher}

Presses universitaires de Rennes

\section{Printed version}

Date of publication: 16 August 2021

Number of pages: $175-178$

ISBN: 978-2-7535-8587-4

ISSN: 1960-1360

Electronic distribution by Cairn

\section{CAIRN INFO}

CHERCHER, REPÉRER, AVANCER.

\section{Electronic reference}

Roland Linck, Jens Fischer and Rebecca Casement, "Chances of Airborne SAR in the Investigation of Buried Archaeological Sites in Moist Soil in Bavaria", ArcheoSciences [Online], 45-1 | 2021, Online since 16 August 2021, connection on 30 August 2021. URL: http://journals.openedition.org/archeosciences/ 9413 ; DOI: https://doi.org/10.4000/archeosciences.9413 


\title{
Chances of Airborne SAR in the Investigation of Buried Archaeological Sites in Moist Soil in Bavaria
}

\author{
Roland LincK ${ }^{\mathrm{a}}$, Jens Fischer ${ }^{\mathrm{b}}$ and Rebecca Casement ${ }^{\mathrm{c}}$
}

\author{
Highlights: \\ - Use of Airborne SAR for detecting buried archaeology. \\ - Evaluation of penetrative capabilities of SAR in moist areas. \\ - Use of high resolution fully polarimetric SAR data in X-, C-, S-\&L-band.
}

Keywords: Bavaria, Remote Sensing, Roman archaeology, Synthetic Aperture Radar, SAR.

\section{INTRODUCTION}

In the last few years, the use of Synthetic-Aperture-Radar (SAR) has become quite widespread owing to a dramatic improvement of the resolution of the corresponding sensors. After the first tests at sites in Syria (Linck, 2013; Linck et al., 2013), several further works have been published in recent years (e.g. Chen et al., 2016; Stewart et al., 2016; Lasaponara \& Masini, 2019; Tapete \& Cigna, 2019). All of these previous studies have two things in common: they are mainly investigating sites in desert and/or arid region and they are using satellite SAR data. With the use of Airborne SAR data, the resolution can be further improved due to the lower flight altitude, especially by applying a circular flight. Within this project, the chances of detecting buried archaeological remains in humid regions of Bavaria shall be investigated. All results are in-situ checked by previous GPR surveys of the Bavarian State Department of Monuments and Sites (BLfD).

\section{USED SENSOR}

One of the world's most advanced civil airborne SAR sensors, F-SAR, operated by the Microwaves and Radar Institute of the German Aerospace Center in Oberpfaffenhofen, offers huge chances for this project, as it is fully polarimetric and provides data from four different frequencies (X-, C-, S- and L-band) that can be easily compared as they are acquired simultaneously. The sensor platform is mounted to a Dornier Do-228-212 research aircraft of the DLR (Fig. 1). F-SAR is mainly used in environmental and geological research. For the first time, this sensor now is used in the field of archaeological prospection. The following case studies show only the results of the L-band, as this channel offered the best penetration depth into the moist soil.

\footnotetext{
${ }^{a}$ Corresponding author, Bavarian State Department of Monuments and Sites, Ref. Z V: Zentrallabor \& Geo-Erkundung, Hofgraben 4, 80539 Munich, Germany, Ludwig-Maximilians-University, Dept. of Earth and Environmental Sciences, Geophysics, Theresienstr. 41, 80333 Munich, Germany

b German Aerospace Center, Microwaves and Radar Institute, Muenchner Straße 20, 82234 Wessling, Germany

' Ludwig-Maximilians-University, Dept. of Earth and Environmental Sciences, Geophysics, Theresienstr. 41, 80333 Munich, Germany
} 


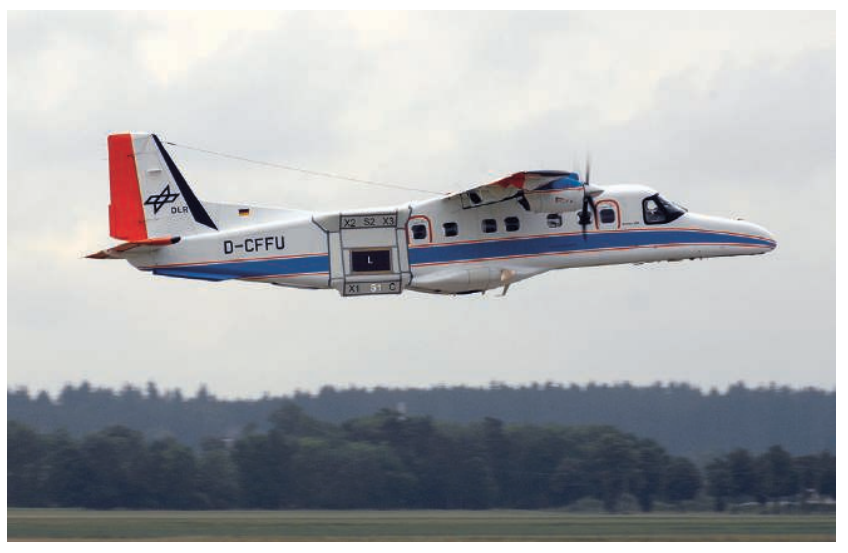

Figure 1. Photograph of the DLR research aircraft Dornier Do-228-212 showing the SAR antenna positions (C DLR).

\section{Case STUdies}

\section{Roman road at Eining (Lkr. Kelheim)}

The Roman fortress of Eining-"Abusina" has a special strategic position, as it is located at the Eastern end of the Raetic Limes. The fortress and its corresponding vicus, i.e. the civil settlement, is accessible by three main roads from the North, the South and the East. They are linked via a bypass around the Eastern limit of the fortress.

Nowadays, nothing is visible at the surface anymore and there is even no evidence in the terrain model. Figure 2 (left) only shows some faint negative crop marks in the grass that indicate the buried remains. One part of the southern road, including the junction with the bypass, had already been investigated with GPR in 2009 by the BLfD. The corresponding depth slices show the Roman pavement in a depth between $20 \mathrm{~cm}$ and $100 \mathrm{~cm}$ below the modern surface on a length of $60 \mathrm{~m}$ (Fig. 2 middle). A detailed investigation of the F-SAR data now reveals that, especially in the L-band, which provides significant penetration depth even in moist conditions, the Roman road junction can be traced quite well (Fig. 2 right). It shows up as a slightly darker anomaly due to the scattering of the SAR signal away from the sensor by the buried stone pavement (Casement, 2020). Further archaeological features are visible in the surrounding, especially the vicus area east of the fortress. As the soil moisture at the time of the SAR-flight was comparable to the one during the GPR-survey (DWD, 2009a; DWD, 2014a), it can be concluded that the L-band waves have a minimum penetration depth of $20 \mathrm{~cm}$ in these soil conditions.

\section{Roman villa rustica at Erlstätt (Lkr. Traunstein)}

Our second test site was the Roman villa rustica near Erlstätt. This site belongs to a series of luxurious imperial farms along the Roman "Via Iulia" that runs from the Raetic capital Augsburg-“Augusta Vindelicum” towards Salzburg"Iuvavum".

The main building of the Villa rustica has a size of $70 \mathrm{~m} \times 35 \mathrm{~m}$. It was investigated by GPR in 2009 . The results reveal in $20-240 \mathrm{~cm}$ depth the layout of a building resembling estates known from Italy (Fig. 3 middle). Whereas the upper $100 \mathrm{~cm}$ belong to the still preserved walls that create a small heap of rubble even visible today in a high-resolution UAV elevation model (Fig. 3 left), the
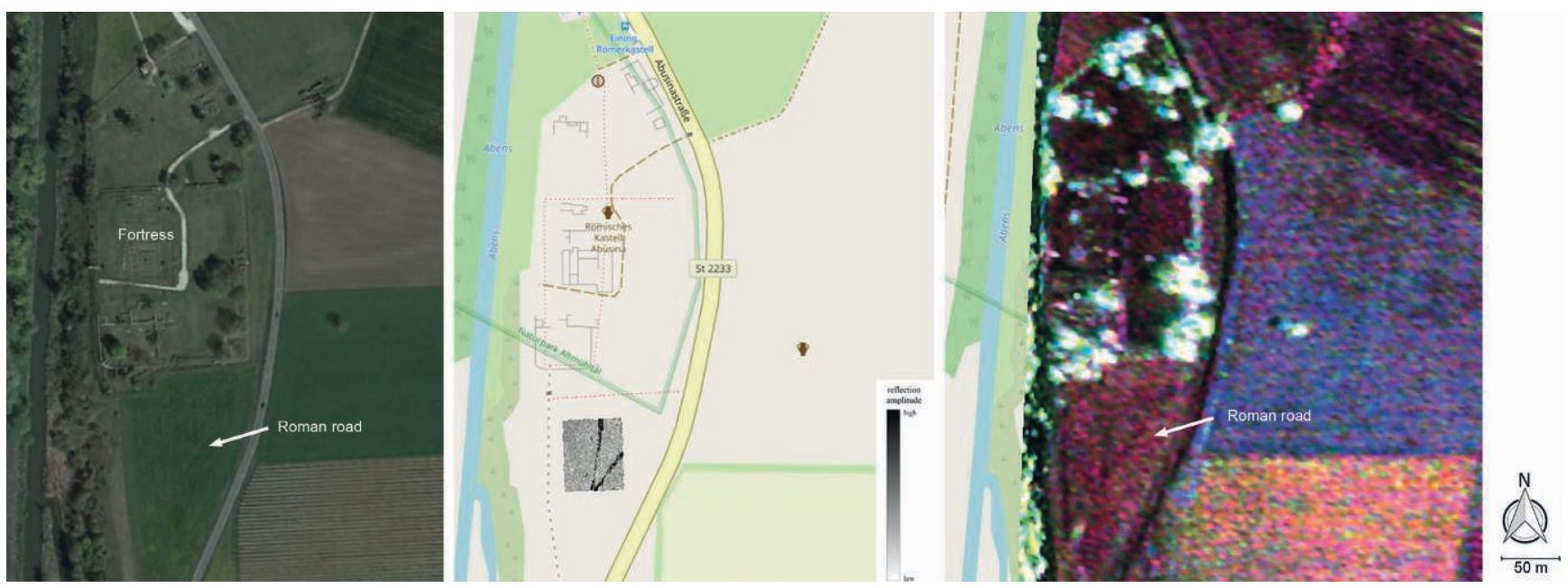

Figure 2. Roman road of Eining: Optical satellite image (C Google Earth) (left); GPR depth slice of 40-60 cm below the modern surface, GSSI SIR-3000 with $400 \mathrm{MHz}$ antenna, sample density: $2 \times 50 \mathrm{~cm}$, grid size: $60 \times 50 \mathrm{~m}$ (C BLfD) (middle); F-SAR L-band Stripmap image, resolution: $60 \times 129 \mathrm{~cm}$ (C DLR) (right). 

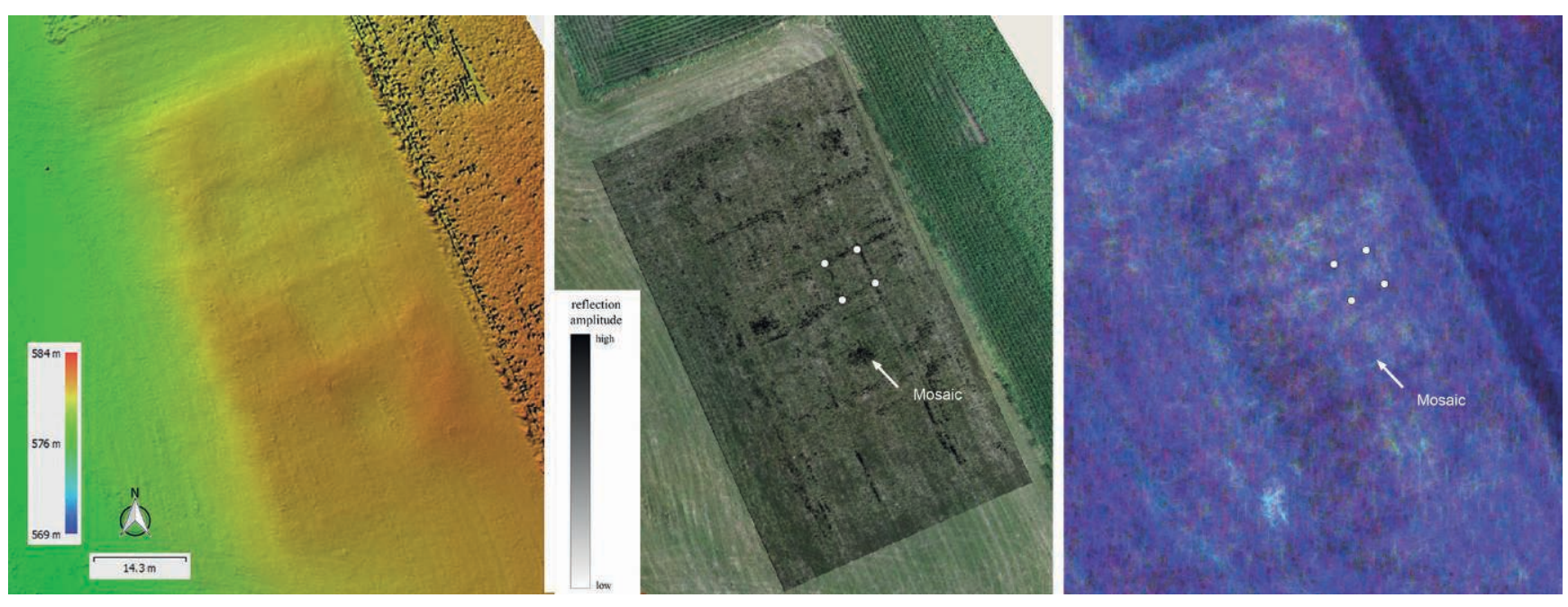

Figure 3. Roman villa rustica of Erlstätt: UAV based DEM; DJI Inspire 2 with Zenmuse X4S camera, date: 30/06/2020, resolution: $2 \mathrm{~cm}$ (@) BLfD) (left); GPR depth slice of 100-120 cm, GSSI SIR-3000 with $400 \mathrm{MHz}$ antenna, sample density: $2 \times 50 \mathrm{~cm}$, grid size: $60 \times 50 \mathrm{~m}$ (@ BLfD) (middle); F-SAR L-band circular flight, resolution: $6 \times 6 \mathrm{~cm}$ (@ DLR) (right). The white points mark a small room of the main building with ca. $6 \mathrm{~m}$ size.

lower $120 \mathrm{~cm}$ depict the foundations with hypocausts below some preserved mosaic floors.

For this case study, it was even possible to acquire an F-SAR circular flight around the site to further improve the L-band resolution to $6 \mathrm{~cm}$ (Fig. 3 right). A detailed comparison with the GPR data shows that even the quite faint linear walls of the Roman building are detectable in the SAR image, and the principal layout of the main building can be visualized by F-SAR (Casement, 2020). Some of the bigger two-dimensional features can possibly be assigned to preserved mosaic floors. The archaeological features in this case study probably show up so clearly, because they create a soil moisture difference that is recognized by the F-SAR sensor. Again, the soil moisture was the same than during the GPR survey, but both are significantly higher than in Eining (DWD, 2009b; DWD, 2014b). Hence, in this case study a conclusion for the penetration depth is difficult.

\section{Conclusion}

The presented case studies show impressively the great chances that Airborne SAR with a high-resolution sensor provides for the archaeological prospection even in humid areas.

Whereas bigger features, like roads can be directly mapped with SAR, smaller ones will only become visible by changing the backscattering due to varying soil moisture. Nevertheless, the archaeological remains can be mapped in detail in both circumstances. Of course, the main limitation for the widespread use of this survey method are the huge costs for such data (ca. 30,000€-50,000€ per flight day). Hence, it is only possible to integrate this method into standard fieldwork within a cooperation with a national space agency or another company that is operating such a system. Another possibility is to use stacks of spaceborne SAR data and to average them along the stack direction. In this way, the effective resolution can be increased. This, as well, has been demonstrated using this airborne data set by averaging across three passes.

\section{References}

Casement, R., 2020. An Evaluation of the Penetrative Capabilities of Airborne Radar in the Study of Archaeological Sites in Bavaria. Master thesis, LMU München, Germany.

Chen, F., Masini, N., Liu, J., You, J., Lasaponara, R., 2016. Multi-frequency satellite radar imaging of cultural heritage: the case studies of the Yumen Frontier Pass and Niya ruins in the Western Regions of the Silk Road Corridor. International Journal of Digital Earth, 9(12): 1224-1241.

DWD, 2009a: Agrarmeteorologischer Monatsbericht für Bayern für den Monat Juli 2009, Ausgabe Nordbayern - Deutscher Wetterdienst (Freising).

DWD, 2009b: Agrarmeteorologischer Monatsbericht für Bayern für den Monat Juli 2009, Ausgabe Südbayern - Deutscher Wetterdienst (Freising).

DWD, 2014a: Agrarmeteorologischer Monatsbericht für Bayern für den Monat Mai 2014, Ausgabe Nordbayern - Deutscher Wetterdienst (Freising). 
DWD, 2014b: Agrarmeteorologischer Monatsbericht für Bayern für den Monat Mai 2014, Ausgabe Südbayern - Deutscher Wetterdienst (Freising).

Lasaponara, R., Masini, N., 2019. Active Satellite Sensors in Cultural Heritage Research: The Use of SAR for Archaeological Prospection. In D.G. Hadjimitsis, K. Themistocleous, B. Cuca, A. Agapiou, V. Lysandrou, R. Lasaponara, N. Masini, G. Schreier (eds.), Remote Sensing for Archaeology and Cultural Landscapes: Best Practices and Perspectives Across Europe and the Middle East. Springer Verlag, Cham, 107-121.

Linck, R., 2013. Methodische Untersuchungen zur Weiterentwicklung der Boden- und Satellitenradarprospektion in der Archäologie. Shaker Verlag, Aachen.
Linck, R., Busche, T., Buckreuss, S., Fassbinder, J.W.E., Seren, S., 2013. Possibilities of archaeological prospection by highresolution X-band satellite radar - a case study from Syria. Archaeological Prospection, 20(2): 97-108.

Stewart, C., Montanaro, R., Sala, M., Riccardi, P., 2016. Feature Extraction in the North Sinai Desert Using Spaceborne Synthetic Aperture Radar: Potential Archaeological Applications. Remote Sensing, 8(10), 825.

Tapete, D., Cigna, F., 2019. COSMO-SkyMed SAR for Detection and Monitoring of Archaeological and Cultural Heritage Sites. Remote Sensing, 11, 1326. 